We are grateful to Dr. J. Dow and Mr. J. Gillespie for their permission to report these cases.

We would like to thank Miss Noel Lansdown and Mr. V. Elliott for their expert technical assistance.

We are particularly grateful to $\mathrm{Mr}$. A. M. Nicholls of Kabi Pharmaceuticals for generous supplies of Kabikinase.

This work was supported by grants from the St. George's Hospital Research Fund and the Medical Research Council.

\section{REFERENCES}

Cotton, L. T., Flute, P. T., and Tsapogas, M. J. C. (1962): Popliteal Artery Thrombosis treated with Streptokinase, Lancet, ii, 1081.

HAWkeY, C. M., and Howell, M. B. (1964): The Laboratory Control of Thrombolytic Therapy, $J$. clin. Path., 17, 287.
Johnson, A. J., and McCarty, W. R. (1959): The Lysis of Artificially Induced Intravascular Clots in Man by Intravenous Infusions of Streptokinase, J. clin. Invest., 38, 1627.

McNicol, G. P., ReID, W., BaIN, W. H., and Douglas, A. S. (1963): Treatment of Peripheral Arterial Occlusion by Streptokinase Perfusion, Brit. med. J., i, 1508.

Tillett, W. S., Johnson, A. J., and MoCarty, W. R. (1955): Intravenous Infusion of the Streptococcal Fibrinolytic Principle (Streptokinase) into Patients: J. clin. Invest., 34, 169.

Verstraete, M., Amery, A., and Vermylen, J. (1963): Feasibility of Adequate Thrombolytic $\vec{\omega}$ Therapy with Streptokinase in Peripheral Arteria! $\Omega$ Occlusions, Brit. med. J., i, 1499.

\title{
CROHN'S DISEASE OF THE STOMACH?
}

\author{
G. A. KUNE, M.B., F.R.C.S., F.R.A.C.S.*, \\ Senior Surgical Registrar. \\ Jane Fullerton, M.B., B.Ch., D.P.H., F.C.Path., \\ Consultant Pathologist.
}

St. Olave's Hospital, London, S.E.16.

ThE CONDITION now known as regional ileitis was established as a clinical, radiological and pathological entity by Crohn, Ginzburg and Oppenheimer in 1932. The histological nature of this disease was further underlined by Hadfield in 1939. Regional ileitis was thus established as a disease of unknown ætiology, characterised by a thickened segment of ileum, consisting histologically of non-caseating granulomatous foci, together with a granulomatous involvement of the regional lymph nodes. Skip areas in the bowel were described as a typical feature of the condition.

This type of granulomatous condition affecting the ileum together with the colon (Crohn, 1949), and cases involving the colon alone (Armitage and Wilson, 1950), were later described. Regional ileitis, together with the involvement of the upper gastrointestinal tract was also reported (Rose 1949, Martin and Carr 1953, Richman, Seifer, Winkelstein, Kirschner and Steinhardt 1955, Miller, Sandweiss and Schwachmann 1956). Finally, cases have been described where this granulomatous condition affects the stomach alone.

Because of its comparative rarity and interest, a further case of isolated granulomatous gastritis is reported.

\section{Case Report}

Mr. W.F., a 57 year old caretaker, first presented at this hospital in August 1953. He gave a 15-year history of recurrent episodes of pain in the epigastrium and right hypochondrium. The pain would start one hour after a meal, persist for about 10 minutes and was occasionally associated with vomiting. He was tender in the epigastrium and

*Present address: The Lahey Clinic, Dept. of Surgery, 605 Commonwealth Avenue, Boston, U.S.A. right hypochondrium. There were no other abnormal physical signs. A barium meal and gastroscopy done at that time showed no abnormality.

Operation. While in hospital, he developed severe acute pain in the epigastrium. A tender gall-bladde was palpable. At operation the gall-bladder was distended and contained stones. The common biles duct was dilated and there was a large stone at its lower end. A cholecystectomy with choledocholithotomy was performed. He made an uneventful recovery.

Two months post-operatively his original symptoms of epigastric pain and vomiting recurred and persisted since.

Investigations. Over the next 7 years he was re-admitted to hospital on several occasions and followed regularly as an out-patient. The following is a summary of the investigations done over that interval.

July 1955 and

February 1956 Barium meals-No abnormality seen.

November 1960 and

March 1961 Gastroscopies-No abnormality seen.

May $1961 \quad$ Barium meal-There was a persistent irregularity of the lesser curvature of the stomach, near the pyloric antrum, probably an ulcer.

Because of his recurrent symptoms and barium meal findings, he was re-admitted in May 1961, for consideration of a further laparotomy. He was noted to have clubbing of the fingers for the first time. There were no other abnormal physical signs.

Operation. At operation there were numerous adhesions present around the porta hepatis and in the upper abdomen generally, but otherwise no abnormality was found.

His symptoms persisted following this operation in spite of intensive medical treatment which included hospitalization and bed rest, antacids, antispasmodics, sedatives and tranquilizers.

Investigations. He was followed as an out-patient for the next two years and had a battery of in- 


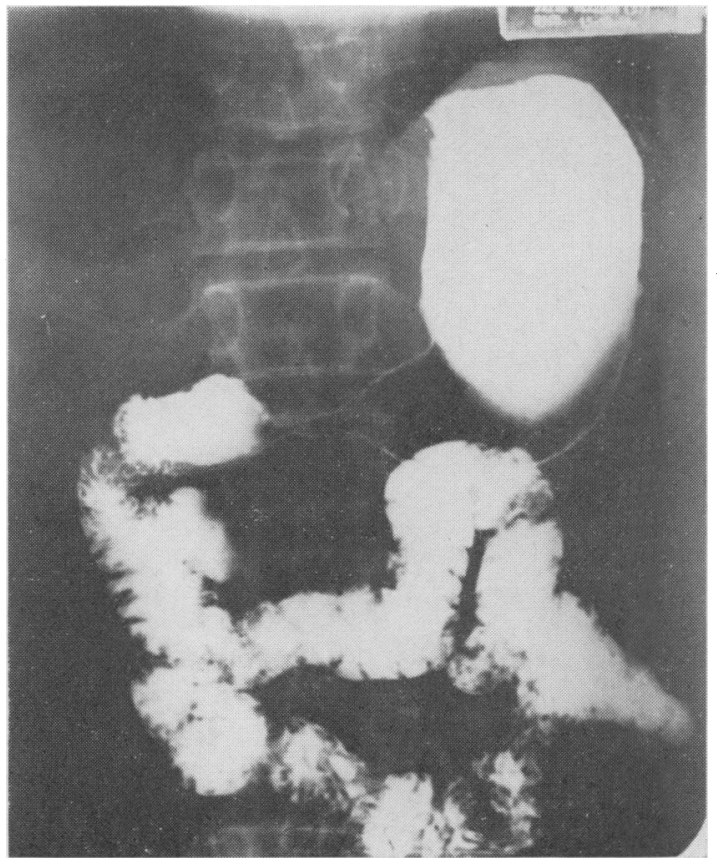

FIG. 2.-Low-power view of the stomach (x55): of the distal third of the stomach. Note almost complete loss of mucosal folds in the stomach.

vestigations performed, which are summarized below:August and

September 1961 Hæmoglobin 13 g./100 ml. W.R. and Kahn test-negative. Serum Amylase-within normal limits during an attack of pain lasting 1 day. $\mathrm{X}$-ray chest-bilateral emphysema noted. Barium enema-no abnormality.

March 1962 Barium meal-a shallow gastric ulcer was seen on the upper third of the lesser curvature. A diverticulum of the second part of the duodenum was noted.

May 1962 Gastroscopy-the gastric rugæ were poorly developed.

August 1962 Gastroscopy-once again gastric atrophy was noted.

$R e-A d m i s s i o n$. He was re-admitted to hospital in October 1963. Epigastric pain and vomiting were still prominent symptoms, but over the preceeding 6 months he had developed anorexia and had lost 3 stone in weight. Except for clubbing of the fingers, there were no abnormal physical signs. A barium meal done on this occasion showed a constant narrowing and rigidity of the distal third of the stomach. There was an almost complete loss of mucosal folds in the whole of the stomach (Fig. 1). These appearances were strongly suggestive of a carcinoma of the stomach, of the linitis plastica type. The duodenal diverticulum was again noted.

Operation. At operation the stomach was considerably thickened, particularly in its distal half, but it was quite supple and freely mobile. There was a healed gastric ulcer at the lower end of the lesser curve. The regional lymph nodes were not enlarged. There were numerous adhesions in the upper

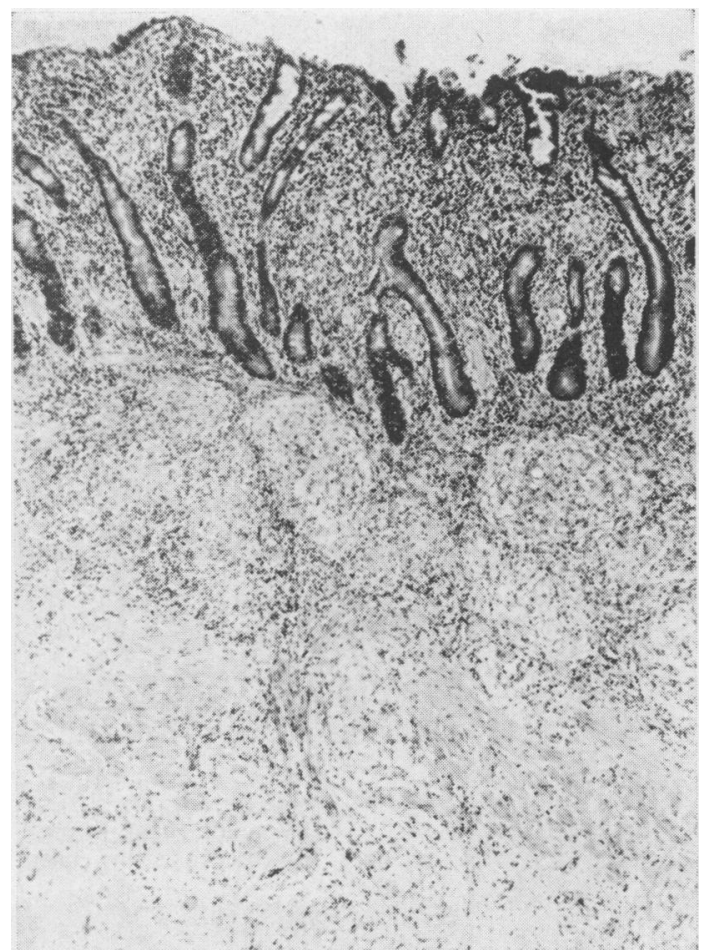

FIG. 2.-Low-power view of the stomach (x55); Notice atrophy of the gastric mucosa. All of the layers of the stomach are infiltrated by lymphocytes and focal granulomata.

abdomen. There was no other abnormality. A Polya-type sub-total gastrectomy was performed. He had a persistent pyrexia post-operatively and discharged a large quantity of pus through the upper end of the incision 3 weeks after the operation. His temperature settled and his general condition rapidly improved after this, but he had obviously developed a large gastric fistula. This slowly healed over the next four weeks.

Pathology. Macroscopic examination of the specimen showed a gross thickening of the stomach. The gastric rugæ were pale and flattened and had a cobblestone appearance seen in cases of regional ileitis. There was no mucosal ulceration.

Microscopical examination of sections taken from several parts of the specimen showed an atrophy of the gastric mucosa. The layers of the stomach were infiltrated by lymphocytes and there were numerous focal granulomata present in all the layers (Fig. 2). Giant cells were associated with each granuloma, but there was no evidence of necrosis or caseation (Fig. 3). Sections examined under polarized light showed typical Schaumann bodies containing crystals (Fig. 4). Sections examined for acid fast bacilli and fungi were negative.

Investigations. Because of these findings, further investigations were carried out:-

Serum Proteins-Total 6.5 g./100 ml.; electrophoresis-slightly decreased albumin and raised Alpha, globulin. Liver Function Tests-Bilirubin $0.3 \mathrm{mg} . / 100 \mathrm{ml}$. Alkaline Phosphatase 10 units. Thymol Flocculation-negative. Blood film-no abnormality seen. Hæmoglobin $15.3 \mathrm{~g} / 100 \mathrm{ml}$. 


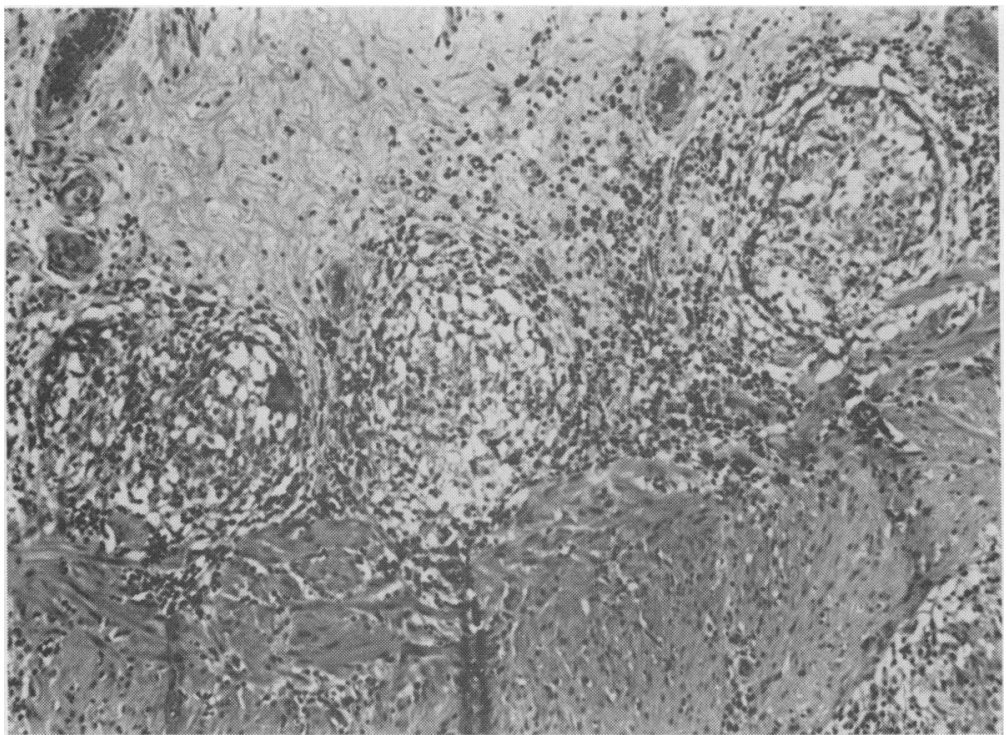

FIG. 3.-Three focal granulomata shown in the submucosa (x110). Giant cells are associated with each granuloma, and there is no evidence of necrosis or caseation.

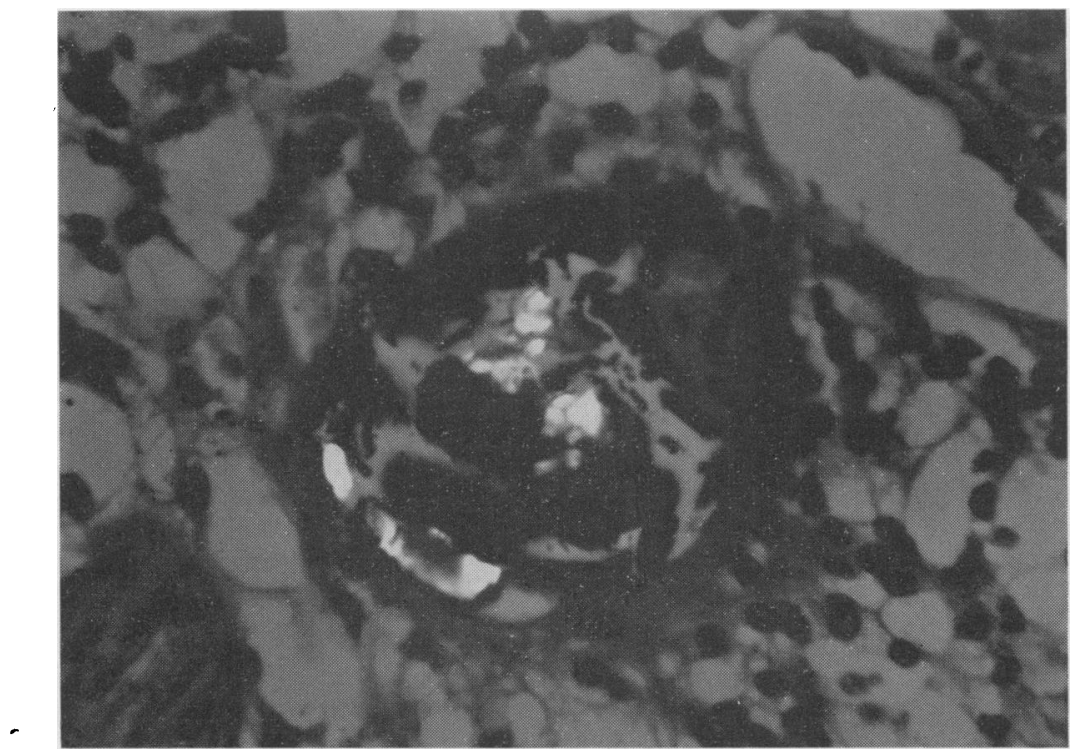

FIG. 4.-High-power view of part of a granuloma under polarized light (x530). This shows a typical Schaumann body containing crystals.

WBC 4,300/cu. mm. The differential count was within normal limits. $X$-ray chest - Bilateral emphysema. X-ray hands-No abnormality. Mantoux $\rightarrow$ Positive 1 in 1,000 old tuberculin. W.R. and Kahn test-Negative. Kveim Test-Negative.

Intradermal skin tests and subsequent skin biopsies to antigen prepared from tissue involved in Crohn's disease of lymph glands, ileum and colon were all negative.
Barium examination (done 4 months post-operatively) - there were no visible mucosal folds in the gastric remnant, but otherwise the oesophagus, gastric remro nant and small bowel were normal.

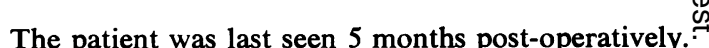
$\mathrm{He}$ had not gained any weight and still complained of disabling post-prandial epigastric pain and vomiting. 
TABLE 1

\section{THE CLINICAL FEATURES OF REPORTED CASES OF ISOLATED GRANULOMATOUS GASTRITIS.}

\begin{tabular}{|c|c|c|c|c|c|c|c|c|}
\hline No. & Author & $\begin{array}{l}\text { Age } \\
\text { Sex }\end{array}$ & $\begin{array}{l}\text { Clinical } \\
\text { Features }\end{array}$ & $\begin{array}{l}\text { Physical } \\
\text { signs }\end{array}$ & $\begin{array}{l}\text { Histamine } \\
\text { test meal }\end{array}$ & Barium meal & Gastroscopy & Other tests \\
\hline 1 & $\begin{array}{l}\text { Gore and Mc- } \\
\text { Carthy, } 1944 \ldots\end{array}$ & $26 \mathrm{M}$ & $\begin{array}{l}\text { P a i n, vomiting, } \\
\text { weight loss } \quad \cdots\end{array}$ & 一 & - & $\begin{array}{l}\text { Cone shaped rigid } \\
\text { deformity of antrum } \\
\text { diagnosed as } \\
\text { cinoma } \\
\text { car- }\end{array}$ & - & $\begin{array}{l}\text { W.R. negative. } \\
\text { Mantoux - negative. } \\
\text { X-ray hands N.A.D. }\end{array}$ \\
\hline 2 & $\begin{array}{c}\text { Appell and others, } \\
1951 \quad \ldots \quad \ldots\end{array}$ & $48 \mathrm{~F}$ & $\begin{array}{lrr}\text { Vomiting, } & \text { weight } \\
\text { loss } & \ldots & \ldots\end{array}$ & 一 & $\begin{array}{l}\text { Achlor- } \\
\text { hydria }\end{array}$ & $\begin{array}{l}\text { Pyloric obstruction } \\
\text { due to carcinoma }\end{array}$ & 一 & W.R. negative. \\
\hline 3 & McKusick, 1953 & $49 \mathrm{~F}$ & $\begin{array}{l}\text { P a i n, vomiting, } \\
\text { weight loss }\end{array}$ & - & $\begin{array}{l}\text { Achlor- } \\
\text { hydria }\end{array}$ & 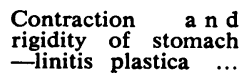 & - & W.R. negative. \\
\hline 4 & $\begin{array}{c}\text { Scott and others, } \\
1953 \quad \ldots \quad \ldots\end{array}$ & $25 \mathrm{M}$ & $\begin{array}{ll}\begin{array}{l}\text { Anorexia, } \\
\text { vomiting, }\end{array} & \begin{array}{l}\text { p a i n } \\
\text { haema- } \\
\text { temesis }\end{array} \quad \ldots \quad \quad \ldots\end{array}$ & 一 & 一 & - & $\begin{array}{l}\text { Gastric } \\
\text { atrophy }\end{array}$ & 一 \\
\hline 5 & Self, 1957 & $35 \mathrm{~F}$ & 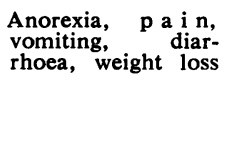 & 一 & - & 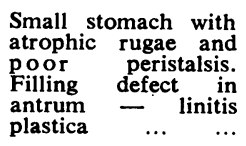 & 一 & W.R. negative. \\
\hline 6 & $\begin{array}{l}\text { Eckstein } \\
\text { Parker, } 1958 \ldots\end{array}$ & $38 \mathrm{M}$ & Pain, weight loss & 一 & - & $\begin{array}{l}\text { Rigid pyloric antrum } \\
\text {-linitis plastica } \ldots\end{array}$ & - & $\begin{array}{l}\text { W.R. negative. } \\
\text { Mantoux }- \text { negative. }\end{array}$ \\
\hline 7 & Bruce and Daber, & ? $\mathrm{F}$ & $\begin{array}{l}\text { P a i n, romiting, } \\
\text { weight loss } \quad \ldots\end{array}$ & 一 & $\begin{array}{l}\text { Achlor- } \\
\text { hydria }\end{array}$ & $\begin{array}{l}\text { Small stomach with } \\
\text { atrophic rugae and } \\
\text { no peristalsis }- \text { lin- } \\
\text { itis plastica } \\
\text {... }\end{array}$ & $\begin{array}{l}\text { Gastric } \\
\text { atrophy }\end{array}$ & $\begin{array}{l}\text { X-ray chest N.A.D. } \\
\text { X-ray hands N.A.D. } \\
\text { Mantoux - positive. }\end{array}$ \\
\hline 8 & $\begin{array}{r}\text { Bowen and Berry, } \\
1961 \quad \ldots \quad r\end{array}$ & $59 \mathrm{~F}$ & 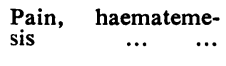 & - & 一 & - & - & - \\
\hline 9 & $\begin{array}{c}\text { F a h i m i } \underset{19}{\text { a n d }} \\
\text { others, } 1963 \ldots\end{array}$ & $51 \mathrm{M}$ & $\begin{array}{l}\text { P a i n, romiting, } \\
\text { weight loss } \quad \ldots\end{array}$ & - & $\begin{array}{l}\text { Achlor- } \\
\text { hydria }\end{array}$ & $\begin{array}{lr}\text { Narrowed } & \text { antrum- } \\
\text { carcinoma } & \ldots\end{array}$ & 一 & - \\
\hline 10 & $\begin{array}{c}\text { F a h i m i } \underset{\text { others, }}{\text { a }} \text { n d } \\
\text { 1963 } \ldots\end{array}$ & $56 \mathrm{~F}$ & 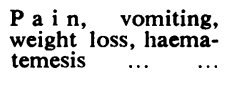 & $\begin{array}{r}\text { Epigastric } \\
\text { tenderness }\end{array}$ & - & $\begin{array}{l}\text { Dilated stomach an- } \\
\text { tral narrowing-car- } \\
\text { cinoma or } \text { healed } \\
\text { ulcer } \\
\text { ulcer }\end{array}$ & 一 & 一 \\
\hline 11 & $\begin{array}{l}\text { F a h i m i a n d } \\
\text { others, } 1963 \ldots\end{array}$ & $47 \mathrm{M}$ & Acute pain & 一 & $\begin{array}{l}\text { Some free } \\
\text { acid }\end{array}$ & $\begin{array}{l}\text { Antral narrowing- } \\
\text { carcinoma } \quad \ldots\end{array}$ & - & 一 \\
\hline 12 & $\begin{array}{c}\text { Kune and Fuller- } \\
\text { ton, } 1964 \quad \ldots\end{array}$ & $57 \mathrm{M}$ & 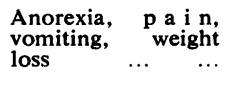 & $\begin{array}{l}\text { Finger } \\
\text { clubbing }\end{array}$ & - & $\begin{array}{l}\text { Narrowing and rigid- } \\
\text { ity of distal stomach } \\
\text { with loss of mucosal } \\
\text { folds-linitis plastica }\end{array}$ & $\begin{array}{l}\text { Gastric } \\
\text { atrophy }\end{array}$ & reported above. \\
\hline
\end{tabular}

\section{Discussion}

The Clinical Features of

Isolated Granulomatous Gastritis

Eleven further cases of well documented isolated granulomatous gastritis have been found in the British and American literature. The clinical features of these are summarized in Table 1 . The sexes are evenly distributed. The ages range from 25 to 59 . The majority of cases have presented with epigastric pain, vomiting and loss of weight. Hæmatemesis was the main presenting symptom in two cases. One case presented as severe epigastric pain of sudden onset. There were no characteristic physical signs. Histamine-fast achlorhydria was present in 4 of the 5 cases where this investigation was done. Gastroscopy was done in 3 cases, all showing gastric atrophy. Barium meal examination was done in 11 cases, and it either showed an appearance resembling linitis plastica or else appearances of an antral carcinoma. A preoperative diagnosis was made in 11 cases and

it is emphasized that in all of these the diagnosis was carcinoma of the stomach, often of the linitis plastica type.

\section{The Management of}

\section{Isolated Granulomatous Gastritis}

The diagnosis will only be made by the pathologist, unless the surgeon is aware of the existence of this uncommon condition. At operation the part of the stomach involved in the granulomatous process will feel thickened and rubbery and there will usually be fleshy regional glands present. The condition may be suspected at operation when, despite extensive gastric involvement, the stomach is relatively mobile, not fixed to any of the adjacent structures, and the omentum, peritoneum and liver are free of metastases. The operation of choice is either partial or total gastrectomy according to the extent of involvement. This was done in 10 of the 11 reported cases and a follow up is reported in 5 cases, all of whom appear to be cured. 
TABLE 2

\section{THE CLASSIFICATION OF GRANULOMATOUS GASTRITIS.}

1. AETIOLOGY KNOWN OR CLASSIFIABLE.

(a) Regional ileitis with gastric involvement.

(b) Sarcoidosis with gastric involvement.

(c) Chronic specific granuloma of the stomach, e.g. tuberculosis.

(d) Reaction to foreign material, e.g. chronic beryllium disease.

(e) Eosinophilic granuloma of the stomach.

2. ISOLATED GRANULOMATOUS GASTRITIS OF UNKNOWN AETIOLOGY.

(a) ? Isolated sarcoidosis. (Sarcoid Reaction).

(b) ? Crohn's disease of the stomach.

(c) ? Reaction to unknown ingested substances.

(d) ?

A gastro-jejunostomy and vagotomy was done in one case, but there is no follow up. In the present case only a partial gastrectomy was done, though the whole of the stomach was involved in the process. The patient continues to have symptoms, probably because we are dealing with an incompletely treated condition. Should he continue to have these disabling symptoms, he will almost certainly come to total gastrectomy.

\section{The Classification of}

\section{Granulomatous Gastritis}

Cases of granulomatous gastritis readily fall into one of two groups (Table 2). In the first group are cases where the cause of the granulomatous condition is either known, e.g. chronic beryllium disease, or else the condition is classifiable as part of a more generalised disease, e.g. sarcoidosis. In the second group are cases of isolated granulomatous gastritis of unknown ætiology. Such a case is reported in this paper. Despite full investigations, it was not possible to classify this condition. The presence of Schaumann bodies with typical inclusion crystals did not help to solve the problem of classification, as the granulomata of sarcoid, non-caseating tuberculosis, intestinal Crohn's disease and chronic beryllium disease are indistinguishable (Jones Williams 1960 and 1964). Indeed it is staggering to note that the response of the tissues to such widely different agents as a bacillus and a metal may be identical.

Should we label this case as "Gastric Sarcoidosis", "Reaction to Unknown Ingested Materials" or "Crohn's disease of the Stomach", as has been done in some of the other cases? Is the stomach that the pathologist examines merely the end-result of tissue response to a number of different agents? Clearly then, attaching an ætiological label to this condition we have got no further in the understanding of the disease, but have only given way to intellectual complacency.
Summary

A case of isolated granulomatous gastritis of unknown æatiology is reported. The clinicaf features of the other reported cases are reviewed: The management and the problems in the classifi cation of this condition are discussed.

We would like to thank Mr. R. A. V. Lewys Lloyd흔 Senior Surgeon, St. Olave's Hospital, London, foren permission to publish this case, and $\mathrm{Dr}$. W. Jones Williams, Institute of Pathology, The Royal Infirmary? Cardiff, who prepared the special histological sections? contributed the Crohn's tissue antigens, and gave us helpful advice in the preparation of this paper.

\section{REFERENCES}

Appell, A. A., Pritzker, H. G., and Klotz, P.G (1951): Pyloric Obstruction of the Stomach? A.M.A. Arch. Surg., 62, 140.

ARmitaGe, G., and Wilson, M. (1950): Crohn's. Disease. A Survey of the Literature and a Report of 34 Cases. Brit. J. Surg., 38, 182.

BowEN, J. C., and BERRY, G. (1961): Non-specifict Granulomatous Disease of the Stomach with Hæmatemesis following Reserpine Therapy. Canad $\bigcirc$ med. Ass. J., 84, 1444.

BRUCE, R. J., and DABER, K. S. (1959): Granuloma of the Stomach. Brit. J. Surg., 46, 379.

CroHN, B. B. (1949): Regional Ileitis. London:T7 Staples Press.

-, GinZBURG, L., and OPPENHEIMER, G. D. (1932) : Regional Ileitis. A Pathologic and Clinical Entity J. Amer. med. Ass., 99, 1323.

ECKSTEIN, H. B., and PARKer, R. A. (1958): Giå̊ cell Granulomatous Thickening of the Gasteros Pyloris of Probable Sarcoid Origin. Brit. J. Suङ:; 45, 659 .

FaHimi, H. D., Deren, J. J., GotTlieb, L. S., ande ZAMCHECK, N. (1963): Isolated GranulomatousGastritis; Its Relationship to Disseminatedo Sarcoidosis and Regional Enteritis, Gastro enterology, 45, 161.

GORE, I., and MCCARTHY, A. M. (1944): Boeck's Sarcoid. Report of a Case Involving the Stomacho Surgery, 16, 865. HADFIELD, G. (1939): The Primary Histologica最
Lesion of Regional Ileitis. Lancet, ii, 773.

JONES WILliaMS, W. (1960): The Nature and Origin of Schaumann Bodies. J. Path. Bact., 79, 193 음 , (1964): Personal Communication.

MCKUSICK, V. A. (1953): Boeck's Sarcoid of the Stomach with Comments on the Aetiology of Regional Ileitis. Gastroenterology, 23, 103.

MARTIN, F. R. R., and CARR, R. J. (1953): Crohn'ş Disease Involving the Stomach. Brit. med. J., i, 700.

MilleR, P. B., SANDWEISS, D. J., and SChWACHMANN, H. (1956): Non-Specific Granulomatous Inflam mation of the Gastrointestinal Tract. New Engl:o J. Med., 255, 501 .

Richman, A., SeIfer, H. D., Winkelstein, A.N KIRSCHNER, P. A., and SteinHARDT, R. D. (1955) Chronic Non-Specific Granulomatous Inflamma N tion of the Stomach, Duodenum and IntestineN Gastroenterology, $29,358$.

Ross, J. R. (1949): Cicatrizing Enteritis, Colitis and Gastritis. Gastroenterology, 13, 344.

SCOTT, N. M., SMITH, V. M., CoX, P. A., and PALMER E. D. (19:53): Sarcoid and Sarcoid-Like Granulomase of the Stomach. A.M.A. Arch. intern. Med., 92; 741 .

Self, J. B. (1957): Crohn's Disease of the Stomach. Postgrad. med. J., 33, 29. 